\title{
Comparison of radon concentrations in soil gas and indoor environment of Afyonkarahisar Province
}

\author{
Hüseyin Ali Yalım ${ }^{1}$ - Ayla Gümüşs ${ }^{1}$ Can Başaran ${ }^{2} \cdot$ Metin Bağcı $^{2} \cdot$ Ahmet Yıldız $^{2}$. Duygu Açil ${ }^{3} \cdot$ Merve Özçelik $^{3}$. \\ Mehmet Zeki İlhan ${ }^{3} \cdot$ Rıdvan Ünal $^{4}$
}

Received: 26 January 2018 / Accepted: 16 April 2018 / Published online: 25 May 2018

(C) Saudi Society for Geosciences 2018

\begin{abstract}
It is well known that radon is the main source of natural radiation exposure to the population. Indoor radon concentrations in an area are affected by ascending radon migration following the convection of groundwater and soil gas along fractures and faults in the bedrock sediments. There are various studies showing that positive radon anomalies in the soil gas are found to coincide with the locations of houses showing the highest concentrations. Moreover, soil gas radon levels and soil permeability are important factors in determining the radon potential of an area, because high permeability enables the increased migration of radon from the soil into houses. Since radon in homes originates mainly from soil gas radon, it is of public interest to study the correlation between soil gas radon and indoor radon in different geographic locations. In the present work, a correlation study was carried in conjunction with radon concentrations in soil gas and indoor environment of Afyonkarahisar Province. The provincial center was assumed to be divided into four regions according to the rock types and tectonic structure to show also the geological structure effect on radon concentrations. The indoor radon concentrations were measured in 74 dwellings using CR-39 passive nuclear track detectors, and the radon concentrations in soil gas were determined in 243 drilled holes using AlphaGUARD detector. The correlation coefficient of 0.97 was obtained between radon concentrations in soil gas and indoor environment of Afyonkarahisar Province.
\end{abstract}

Keywords Soil gas radon $\cdot$ Indoor radon $\cdot$ Geological structure $\cdot$ Afyonkarahisar

\section{Introduction}

It is well known that radon and its decay products consist of about $50 \%$ of the total inhalation doses to human population exposed to the natural radiation sources (Oikawa et al. 2003; Kullab et al. 2001; UNSCEAR 1993, 1988).

This article is part of the Topical Collection on Geo-Resources-EarthEnvironmental Sciences

Hüseyin Ali Yalım hayalim@aku.edu.tr

1 Physics Department, Afyon Kocatepe University, Afyonkarahisar, Turkey

2 Department of Geological Engineering, Afyon Kocatepe University, Afyonkarahisar, Turkey

3 Graduate School of Natural and Applied Sciences, Afyon Kocatepe University, Afyonkarahisar, Turkey

4 Health Services Vocational School, Uşak University, Uşak, Turkey
The epidemiological studies have shown that inhaling radon and its progenies make the public inevitable dealing with an increasing risk of lung cancer (UNSCEAR 2000). Therefore, it is essential to determine the mean of a long-term indoor radon and its decay product levels in the environment and soil gas (Durrani and Ilic 1997; Mehra and Bala 2013). Indoor radon concentrations in an area are affected by ascending radon migration following the convection of groundwater and soil gas along fractures and faults in the bedrock sediments. Several studies have proved that the indoor radon level depends upon various factors like geological features (Choubey et al. 1999; Plant and Saunders 1996; Kulali and Akkurt 2015), soil nature such as temperature and permeability (Fujiyoshi et al. 2006; King and Minissale 1994), meteorological conditions such as air temperature and pressure (Collignan and Powaga 2014; Dolejs and Hulka 2003; Kitto 2005; Narasimhan et al. 1990; Papaefthymiou et al. 2003; Robinson and Sextro 1997; Chauhan et al. 2008), the living style of the dwellers, 
type of building material used for building constructions (Zenginerler et al. 2016; Gupta et al. 2009; Khatibeh et al. 1997; Kumar et al. 2003, 2014; Al-Khateeb et al. 2012), and the degree of ventilation of closed environments (Baeza et al. 2003; Kılınçarslan and Akyol 2016; Mehra et al. 2011; Singh et al. 2011).

Radon is always present in the soil, since it is continuously produced in the decay chain of uranium with a halflife of 4.5 billion years. Therefore, the major part of indoor radon comes from the soil and building materials since the uranium and radium are uniformly distributed in these materials from the time of origination of earth. There are various studies have showing that positive radon anomalies in the soil gas are found to coincide with the locations of houses showing the highest concentrations (Akerblom and Mellander 1997; Barnet 2012; Chen and Ford 2017; Keller et al. 1992; Minda et al. 2009; Neznal et al. 2006; Vaupotic et al. 2002). Moreover, soil gas radon levels and soil permeability are important factors in determining the radon potential of an area, because high permeability enables the increased migration of radon from soil into houses. Since radon in homes originates mainly from the soil gas radon, it is of public interest to study the correlation between soil gas radon and indoor radon in different geographic locations (Chen et al. 2009; Cinelli et al. 2015; Kemski et al. 2009; Kemski et al. 2006; Lara et al. 2015; Mose et al. 1992; Neznal et al. 1996; Patra et al. 2013; Reimer and Szarzi 2005; Sundal et al. 2004; Baykara et al. 2005).

The objective of the present work is to carry out a correlation study between radon concentrations in soil gas and indoor environment of Afyonkarahisar Province. Therefore, the radon concentration measurements were committed both the indoor environment of 74 dwellings and soil gas of 243 holes spread over geologically different parts of Afyonkarahisar Province.

\section{Materials and method}

\section{Geological settings of study area}

The present study was carried out in the midwestern Anatolian city of Afyonkarahisar Province which consists of lithologies related to various geological times from the Paleozoic to the Quaternary. The Paleozoic metamorphic rocks are widespread in the northwest and southeast of the study area. Crystallized limestones, quartzites, and schists are the main metamorphic rocks (Erkan et al. 1996; Metin et al. 1987). Mesozoic rocks have different lithological properties in the study area. Since the northern parts are composed of detrital and carbonates, Triassic-Upper Cretaceous carbonates are widespread in the southeast. Throughout the study area, the Cenozoic units unconformably overlie in the Paleozoic and the Mesozoic rocks and they are composed of gravel, sandy fluvial sediments, limestones, and marl mixed with clay-sand-gravel-tuff in alternation. Since the aim of this study is to expose the correlation between the radon concentrations in soil gas and indoor environment of Afyonkarahisar Province, the study area was assumed to be divided into four regions according to lithological properties and tectonic structure as discussed by reference (Koçyiğit and Deveci 2007). The scheme of lithological properties and tectonic structure in the regions is shown in Fig. 1.

\section{Indoor radon measurements}

The indoor radon activity concentrations were measured by using previously calibrated passive radon dosimeters (CR-39) in 74 dwellings (of which 46 are houses and 28 are workplaces) of Afyonkarahisar (Fig. 2) and these measurements were repeated four times in different seasons of a year to obtain the seasonal variation of the indoor radon levels, too. On the other hand, the study area has been assumed to be divided into four regions according to the rock types and tectonic structure
Fig. 1 Types of soil and rock in the regions

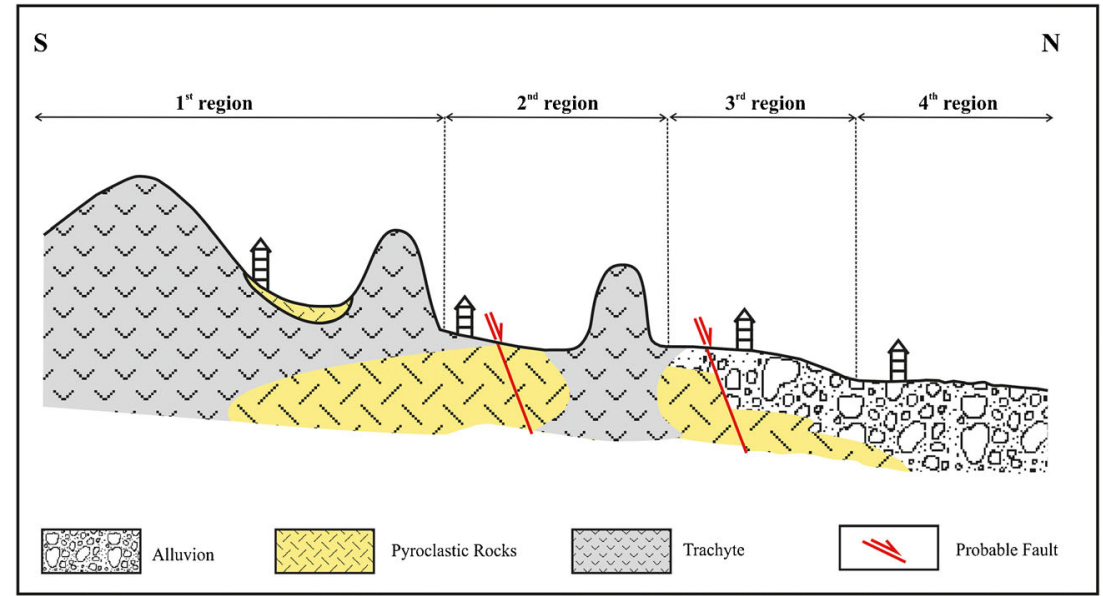


Fig. 2 Indoor radon concentration measurement points

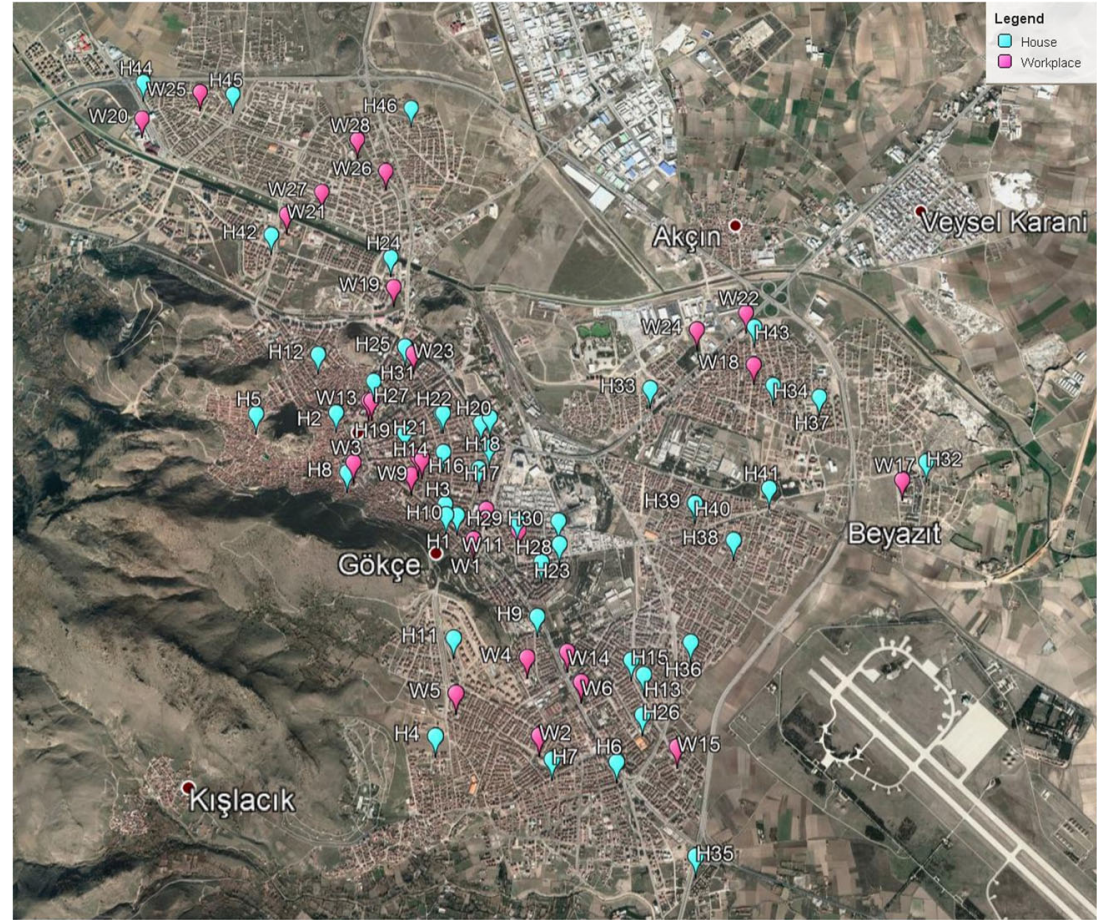

to show the geological structure effect on indoor radon activity concentrations. The dwellings are distributed as 18 in the first region, 29 in the second region, 19 in the third region, and 8 in the fourth region. These numbers are decided with taking the residence densities in the regions into account.

Sampling was done at random selected dwellings where two dosimeters were placed at each sampling point: namely cellars and repositories on the basement. The dosimeters were left to record radon exposure for about 80-90 days. After each exposure time, they were subjected to chemical processing with $\mathrm{NaOH}$ (Radobath system) and then track. A detailed description of the structure and the analysis of the passive dosimeters can be found in the RADOSYS User Manual and elsewhere (Nikolaev and Ilic 1999; RADOSYS 2011).

\section{Soil gas radon measurements}

The radon concentration in soil gas was measured by using the AlphaGuard PQ 2000 radon monitor equipped with a specially designed soil gas unit consists of a drilling rod with an exchangeable drilling tip with airlock which is closed by a rivet and capillary probe. The soil gas was sucked out from the surrounding ground area of a $0.7-\mathrm{m}$ deep hole and pumped with a low flow rate mode into the ionization chamber of the monitor through the capillary probe. The schematic view of the experimental setup is presented in Fig. 3. In order to determine only $222 \mathrm{Rn}$ concentration, the ionization chamber was kept closed tightly after filling it with soil gas for about 10 -min time interval that is needed to neglect the thoron contribution. Detailed information about the experimental setup was given in various previous studies (Alharbi and Abbady 2013; GENTIRON 1998; Vaupotic et al. 2010).

\section{Results and discussion}

The indoor radon concentrations were measured in the basements of 74 dwellings spread over geologically different four parts of Afyonkarahisar Province using previously calibrated passive CR-39 passive nuclear track detectors, and the radon concentrations in soil gas were determined in 243 drilled holes using AlphaGUARD detector. The average soil gas and indoor radon concentration values of the four regions were separately obtained from the corresponding measured concentrations and they are given in Table 1.

The average radon concentrations are in the range of $34,270-72,340 \mathrm{~Bq} \mathrm{~m}^{-3}$ in soil gas, while they are in the range of $209.80-379.70 \mathrm{~Bq} \mathrm{~m}^{-3}$ in the indoor environments of the regions. The average radon concentration values both in soil gas and indoor environments have the minimum and the maximum values in the same region. The present results show the similar accordance in all regions. Therefore, as expected from the previous studies (Akerblom and Mellander 1997; Barnet 2012; Chen and Ford 2017; Keller et al. 1992; Minda et al. 2009; Neznal et al. 2006; Vaupotic et al. 2002), there is also a linear correlation (since a correlation coefficient of $R^{2}=0.97$ obtained) between the soil gas and indoor radon concentrations of Afyonkarahisar Province which is shown in Fig. 4. 
Fig. 3 Schematic view of experimental setup of soil gas radon measurement

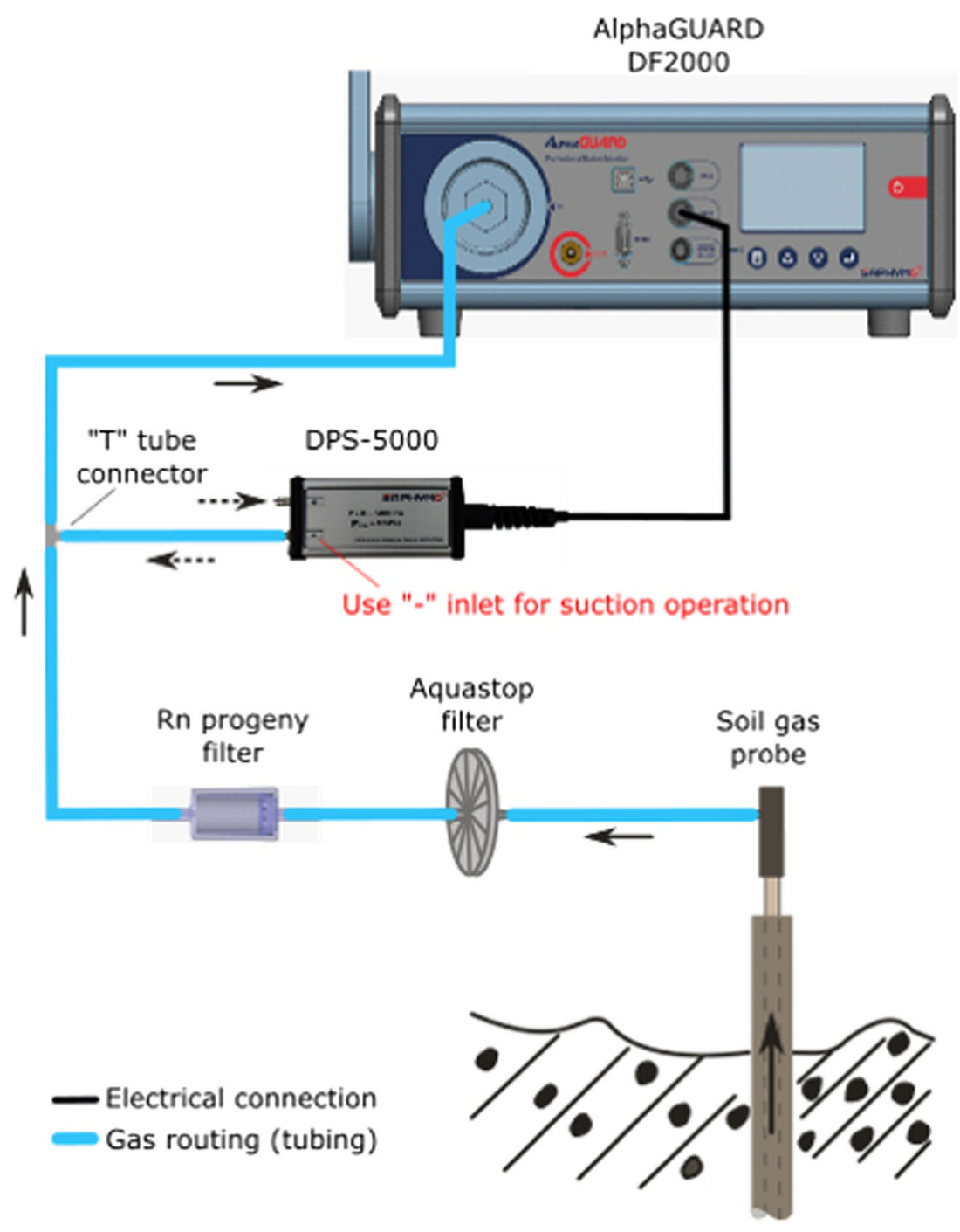

\section{Conclusion}

Since the previous studies indicate that there is a positive correlation between the radon concentration in the indoor environment and the radon concentration in the soil gas of the area where the dwellings are located, this study was conceded to find out the related correlation of the Afyonkarahisar Province. For this objective, the area was assumed to be divided into four regions according to the type of rock content and tectonic and the radon concentration measurements were

Table 1 The average soil gas and indoor radon concentration values of the regions

\begin{tabular}{lllll}
\hline Environment & \multicolumn{4}{l}{ Average radon concentrations $\left(\mathrm{Bq} \mathrm{m}^{-3}\right)$} \\
\cline { 2 - 5 } & 1st region & 2nd region & 3rd region & 4th region \\
\hline Soil gas & 34,270 & 57,840 & 72,340 & 35,550 \\
Indoor & 209.80 & 293.40 & 379.70 & 229.70 \\
\hline
\end{tabular}

carried out both in the indoor environment and soil gas in the geologically different parts. The present results can be concluded as follows:

- The average radon concentration values of soil gas and indoor environments have the similar behaviors in the geologically different regions; i.e., the indoor radon

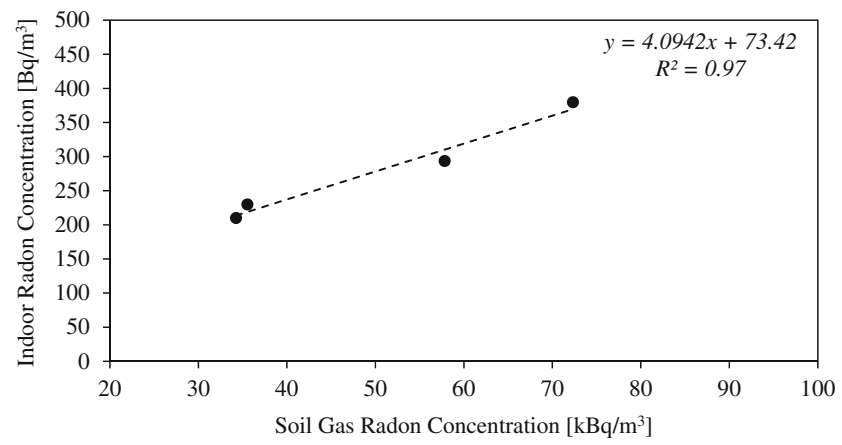

Fig. 4 The correlation between the soil gas and indoor radon concentrations 
concentration of a region and the soil gas radon concentration of the same region are in harmonious each other.

- The minimum radon concentrations were obtained in the first region of the study area, since the region was encrusted by trachyte rocks having the lowest permeability off all geological content.

- The radon concentrations were the maximum in the third region, since the high permeable pyroclastic rock and alluvion are the geological content in the region. Furthermore, the probable fault may be increasing the permeability of the zone.

- The correlation coefficient of 0.97 is a strong evidence of the linear correlation between the soil gas and indoor radon concentrations of Afyonkarahisar Province.

Acknowledgements The authors are also thankful to the director and professional staff of Health Physics Department at Sarayköy Nuclear Research and Training Center, for their valuable help in dosimetry evaluations.

Funding information This work was supported by Turkish Atomic Energy Authority with the grant number A5.H1.P1.06 and Afyon Kocatepe University Science Research Projects Coordination Unit with the grant numbers 17.KARIYER.95, 14.FENBILL.08, and 12.FENBIL.14.

\section{References}

Akerblom G, Mellander H (1997) Geology of radon. In: Radon measurements by etched track detectors. World Scientific Publishing, Singapore, New Jersey, London, Hong Kong, pp 29-49

Alharbi WR, Abbady AGE (2013) Measurement of radon concentrations in soil and the extent of their impact on the environment from AlQassim, Saudi Arabia. Nat Sci 5:93-98. https://doi.org/10.4236/ns. 2013.51015

Al-Khateeb HM, Al-Qudah AA, Alzoubi FY, Alqadi MK, Aljarrah KM (2012) Radon concentration and radon effective dose rate in dwellings of some villages in the district of Ajloun, Jordan. Appl Radiat Isot 70:1579-1582. https://doi.org/10.1016/j.apradiso.2012.04.009

Baeza A, Navarro E, Roldán C, Ferrero JL, Juanes D, Coebacho JA, Guillén FJ (2003) Indoor radon levels in buildings in the autonomous community of Extremadura (Spain). Radiat Prot Dosim. https://doi.org/10.1093/oxfordjournals.rpd.a006142

Barnet I (2012) Indoor radon probability calculated from the Czech soil gas radon data in a grid net for the European geogenic radon map construction: test of feasibility. Environ Earth Sci 66:1149e11531149e1153. https://doi.org/10.1007/s12665-011-1322-3

Baykara O, Dogru M, Inceoz M, Aksoy E (2005) Measurements of radon emanation from soil samples in triple-junction of North and East Anatolian active faults systems in Turkey. Radiat Meas 39:209-212

Chauhan RP, Nain M, Kant K (2008) Radon diffusion studies through some building materials: effect of grain size. Radiat Meas 43:S445S448

Chen J, Ford KL (2017) A study on the correlation between soil radon potential and average indoor radon potential in Canadian cities. $\mathrm{J}$ Environ Radioact 166:152-156. https://doi.org/10.1016/j.jenvrad. 2016.01.018

Chen J, Falcomer R, Ly J, Wierdsma J, Bergman L (2009) Long-term monitoring of soil gas radon and permeability at two reference sites. Radiat Prot Dosim 131:503-508
Choubey VM, Bist KS, Saini NK, Ramola RC (1999) Relation between soil-gas radon variation and different lithotectonic units, Garhwal Himalaya, India. Appl Radiat Isot 51:587-592

Cinelli G, Tositti L, Capaccioni B, Brattich E, Mostacci D (2015) Soil gas radon assessment and development of a radon risk map in Bolsena, Central Italy. Environ Geochem Health 37:305-319

Collignan B, Powaga E (2014) Procedure for the characterization of radon potential in existing dwellings and to assess the annual average indoor radon concentration. J Environ Radioact 137:64-70

Dolejs J, Hulka J (2003) The weekly measurement deviations of indoor radon concentration from the annual arithmetic mean. Radiat Prot Dosim 104:253-258. https://doi.org/10.1093/oxfordjournals.rpd. a006189

Durrani SA, Ilic R (eds) (1997) Radon measurements by etched track detectors: applications to radiation protection, earth science and the environment. World Scientific, Singapore

Erkan Y, Bayhan H, Tolluoğlu Ü, Aydar E (1996) Afyon Yöresi Metamorfik ve Volkanik kayaçlarının Petrografik ve Jeokimyasal İncelenmesi. TÜBİTAK Proje Raporu. YBAG-0044/DPT Projesi Raporu, Ankara. (in Turkish)

Fujiyoshi R, Sakamoto K, Imanishi T, Sumiyoshi T, Sawamura S, Vaupotic J, Kobal I (2006) Meteorological parameters controlling variability of $222 \mathrm{Rn}$ activity concentration in soil gas at a site in Sapporo, Japan. Sci Total Environ 370(1):224-234. https://doi.org/ 10.1016/j.scitotenv.2006.07.007

GENTIRON (1998) AlphaGUARD portable radon monitors user manual

Gupta M, Saini M, Chauhan RP (2009) Measurement of alpha radioactivity in some building construction materials. Asian J Chem 21: S052-S055

Keller G, Schneiders H, Schuetz M, Siehl A, Stamm R (1992) Indoor radon correlated with soil and subsoil radon potential e a case study. Environ Geol Water Sci 19:113-119

Kemski J, Klingel R, Siehl A, Valdivia-Manchego M (2006) Radon risk prediction in Germany based on gridded geological maps and soil gas measurements. In: Barnet I, Neznal M, Pacherova P (eds) Proceedings of the 8th international workshop on the geological aspects of radon risk mapping, pp 139-156 (Prague)

Kemski J, Klingel R, Siehl A, Valdivia-Manchego M (2009) From radon hazard to risk prediction-based on geological maps, soil gas and indoor measurements in Germany. Environ Geol 56:1269-1279

Khatibeh AJAH, Ahmed N, Matiullah Kenawy MA (1997) Natural radioactivity in marbles stones. Jordan. Radiat Meas 28:345-348

Kılınçarslan Ș, Akyol B (2016) Investigation of the effect of selection of construction materials for radiotherapy centers. https://doi.org/10. 12693/APhysPolA.130.441

King CY, Minissale A (1994) Seasonal variability of soilegas radon concentration in Central California. Radiat Meas 23(4):683-692

Kitto ME (2005) Interrelationship of indoor radon concentrations, soilgas flux, and meteorological parameters. J Radioanal Nucl Chem 264(2):381-385. https://doi.org/10.1007/s10967-005-0725-6

Koçyiğit A, Deveci Ș (2007) A N-S-trending active extensional structure, the Şuhut (Afyon) graben: commencement age of the extensional neotectonic period in the Isparta angle, SW Turkey. Turk J Earth Sci $16: 391-416$

Kulalı F, Akkurt İ (2015) Investigation of radon concentrations in Pamukkale-Turkey. https://doi.org/10.12693/APhysPolA.128.B445

Kullab MK, Al-Bataina BA, Ismail AM, Abumurad KM (2001) Seasonal variation of radon-222 concentrations in specific locations in Jordan. Radiat Meas 34:361-364

Kumar R, Sengupta D, Prasad R (2003) Natural radioactivity and radon exhalation studies of rock samples from Surda copper deposits in Singhbhum shear zone. Radiat Meas 36:551-553

Kumar A, Chauhan RP, Joshi M, Sahoo BK (2014) Modelling of indoor radon concentration from radon exhalation rates of building 
materials and validation through measurement. J Environ Radioact 127:50-55. https://doi.org/10.1016/j.jenvrad.2013.10.004

Lara E, Rocha Z, Santos TO, Rios FJ, Oliveira AH (2015) Soil features and indoor radon concentration prediction: radon in soil gas, pedology, permeability and ${ }^{226} \mathrm{Ra}$ content. Radiat Prot Dosim 167:126129

Mehra R, Bala P (2013) Estimation of annual effective dose due to radon level in indoor air and soil gas in Hamirpur district of Himachal Pradesh. J Geochem Explor 142:16-20. https://doi.org/10.1016/j. gexplo.2013.07.005

Mehra R, Badhan K, Kansal S, Sonkawade RG (2011) Assessment of seasonal indoor radon concentration in dwellings of Western Haryana. Radiat Meas 46:1803-1806

Metin S, Genç Ș, Bulut V (1987) Afyon ve dolayının jeolojisi. MTA derleme No: 8103, 74s. Ankara. (in Turkish)

Minda M, Toth G, Horvath I, Barnet I, Hamori K, Toth E (2009) Indoor radon mapping and its relation to geology in Hungary. Environ Geol 57:601-609

Mose DG, Mushrush GW, Chrosniak CE (1992) Soil radon, permeability, and indoor radon prediction. Environ Geol Water Sci 19:91-96

Narasimhan TN, Tsang YW, Holman HY (1990) On the potential importance of transient air flow in advective radon entry into buildings. Geophys Res Lett 17(6):821-824

Neznal M, Neznal M, Smarda J (1996) Assessment of radon potential of soils e a five years experience. Environ Int 22:819-828

Neznal M, Neznal M, Matolin M, Barnet I, Miksova J (2006) The new method for assessing the radon risk of building sites. Project report. State Office for Nuclear Safety, Prague

Nikolaev VA, Ilic R (1999) Etched track radiometers in radon measurements: a review. Radiat Meas 30:1-13

Oikawa S, Kanno N, Sanada T, Ohashi N, Uesugi M, Sato K, Abukawa J, Higuchi H (2003) A nationwide survey of outdoor radon concentration in Japan. J Environ Radioact 65:203-213. https://doi.org/10. 1016/S0265-931X(02)00097-8

Papaefthymiou H, Mavroudis A, Kritidis P (2003) Indoor radon levels and influencing factors in houses of Patras, Greece. J Environ Radioact 65:203-213. https://doi.org/10.1016/S0265-931X(02) 00097-8

Patra AC, Sahoo SK, Tripathi RM, Puranik VD (2013) Distribution of radionuclides in surface soils, Singhbhum Shear Zone, India and associated dose. Environ Monit Assess 185:7833-7843
Plant JA, Saunders AD (1996) The radioactivity earth. Radiat Prot Dosim 68:25-36

RADOSYS (2011) RS_Man81: User's manual. Radosys Kft, Budapest

Reimer GM, Szarzi SL (2005) Indoor radon risk potential of Hawaii. J Radioanal Nucl Chem 264:365-369

Robinson AL, Sextro RG (1997) Radon entry into buildings driven by atmospheric pressure fluctuations. Environ Sci Technol 31(6):1742-1748

Singh B, Singh S, Bajwa BS, Singh J, Kumar A (2011) Soil gas radon analysis in some areas of Northern Punjab, India. Environ Monit Assess 174:209-217. https://doi.org/10.1007/s10661-010-1451-2

Sundal AV, Henriksen H, Lauritzen SE, Soldal O, Strand T, Valen V (2004) Geological and geochemical factors affecting radon concentrations in dwellings located on permeable glacial sedimentsda case study from Kinsarvik, Norway. Environ Geol 45:843-858

UNSCEAR (1988) Sources, effects and risks of ionizing radiations. United Nations Scientific Committee on the effects of atomic radiation. Report to the General Assembly on the Effects of Atomic Radiation. United Nations, New York

UNSCEAR (1993) United Nations Scientific Committee on the effects of atomic radiation. Sources, effects and risks of ionizing radiations. Report to the General Assembly on the effects of atomic radiation. United Nations, New York

UNSCEAR (2000) United Nations Scientific Committee on the effects of atomic radiation. Sources and Effects of Ionizing Radiation. In: Report to the General Assembly with Scientific Annexes, vol. I. United Nations, New York

Vaupotic J, Andjelov M, Kobal I (2002) Relationship between radon concentrations in indoor air and in soil gas. Environ Geol 42: $583-587$

Vaupotic J, Gregoric A, Kobal I, Zvab P, Kozak K, Mazur J, Kochowska E, Grzadziel D (2010) Radon concentration in soil gas and radon exhalation rate at the Ravne Fault in NW Slovenia. Nat Hazards Earth Syst Sci 10:895-899 www.nat-hazards-earth-syst-sci.net/10/ 895/2010/

Zenginerler Z, Ertugral F, Yakut H, Tabar E, Demirci N, Gunermelikoglu $\mathrm{K}$ (2016) Measurement of seasonal indoor radon concentration in Sakarya University, Turkey. https://doi.org/10.12693/APhysPolA. 130.450 